\title{
Characterization of spray-dried Gac aril extract and estimated shelf life of $\beta$-carotene and lycopene
}

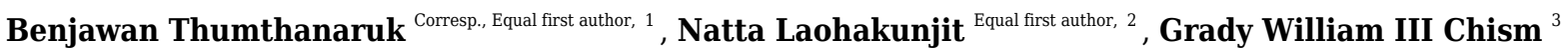 \\ ${ }^{1}$ Department of Agro-Industrial, Food and Environmental Technology, Faculty of Applied Science, King Mongkut's University of Technology North Bangkok, \\ Bangkok, Thailand \\ 2 School of Bioresources and Technology, King Mongkut's University of Technology Thonburi, Bangkok, Thailand \\ 3 Department of Biology, Indiana University-Purdue University at Indianapolis, Indianapolis, Indiana, United States \\ Corresponding Author: Benjawan Thumthanaruk \\ Email address: benjawan.t@sci.kmutnb.ac.th
}

Background. Fresh Gac (Momordica cochinchinensis) fruit is rich in carotenoids, mainly $\beta$-carotene and lycopene, but these compounds are sensitive to degradation. Spray drying is used to encapsulate the sensitive $\beta$-carotene and lycopene with different materials. Only a few reports of using HBCD have been published. Additionally, studies of $\beta$-carotene and lycopene losses in Gac powders during storage are limited. Therefore, the encapsulation of $\beta$-carotene and lycopene of Gac aril with HBCD by spray drying at different inlet temperatures were compared. The shelf life of $\beta$-carotene and lycopene during storage was also calculated.

Methods. The fresh Gac aril was separated and kept frozen before the experiment. Gac aril and water ( $1: 5 \mathrm{w} / \mathrm{v}$ ) were centrifuged at $8,000 \mathrm{~g}$ at $20^{\circ} \mathrm{C}$ for $15 \mathrm{~min}$ using a high-speed centrifuge (Sorval, Dupont, U.S.A.). The supernatant was filtered twice and concentrated until $15^{\circ}$ Brix using a rotary evaporator (R-200, Buchi, Switzerland). The mixture of concentrated aril extract and cyclodextrin at 5\% (w/v) was dried at three inlet temperatures by a spray dryer (B-290, Buchi, Switzerland) with drying air flow rate, compressor air pressure, and feed rate set at $473 \mathrm{~L} / \mathrm{h}, 40 \mathrm{~m}^{3} / \mathrm{h}$, and $3 \mathrm{~mL} / \mathrm{min}$, respectively. The physicochemical qualities, particle image morphology, and estimated storage time of $\beta$-carotene and lycopene were determined.

Results. Increased inlet temperatures of spray drying decreased the bulk density, $\beta$-carotene, and lycopene content of spray-dried powders significantly. The color values of dried powders had significant differences in yellowness $\left(b^{*}\right)$ and chroma, but not lightness $\left(L^{*}\right)$, redness $\left(a^{*}\right)$, and hue when the inlet temperature increased from $160^{\circ} \mathrm{C}$ to $180^{\circ} \mathrm{C}$. The maximum reduction of $\beta$-carotene and lycopene observed during storage at $55^{\circ} \mathrm{C}$ was $90.88 \%$ and $91.11 \%$ for 33 and 18 days. For $\beta$-carotene, the estimated shelf-life (retention of $50 \%$ of $\beta$-carotene) was $9.9,48.4$, and 91.6 days at $25^{\circ} \mathrm{C}, 10^{\circ} \mathrm{C}$, and $4^{\circ}$ C. The shelf-life of lycopene was 26,176 , and 357 days at $25^{\circ} \mathrm{C}, 10^{\circ} \mathrm{C}$, and $4^{\circ} \mathrm{C}$, respectively. $\mathrm{HBCD}$ could be potentially used as an encapsulating agent in spray-dried Gac aril, but the shelf-life of $\beta$-carotene and lycopene needs to be improved to be useful as a food ingredient. 


\section{Characterization of spray-dried Gac aril extract and estimated shelf-}

\section{2 life of $\beta$-carotene and lycopene}

3

4

5

\section{Abstract}

Background. Fresh Gac (Momordica cochinchinensis) fruit is rich in carotenoids, mainly $\beta$ carotene and lycopene, but these compounds are sensitive to degradation. Spray drying is used to encapsulate the sensitive $\beta$-carotene and lycopene with different materials. Only a few reports of using HBCD have been published. Additionally, studies of $\beta$-carotene and lycopene losses in Gac powders during storage are limited. Therefore, the encapsulation of $\beta$-carotene and lycopene of Gac aril with HBCD by spray drying at different inlet temperatures were compared. The shelf life of $\beta$-carotene and lycopene during storage was also calculated.

Methods. The fresh Gac aril was separated and kept frozen before the experiment. Gac aril and water $(1: 5 \mathrm{w} / \mathrm{v})$ were centrifuged at $8,000 \mathrm{~g}$ at $20^{\circ} \mathrm{C}$ for $15 \mathrm{~min}$ using a high-speed centrifuge (Sorval, Dupont, U.S.A.). The supernatant was filtered twice and concentrated until $15^{\circ}$ Brix using a rotary evaporator (R-200, Buchi, Switzerland). The mixture of concentrated aril extract and cyclodextrin at 5\% (w/v) was dried at three inlet temperatures by a spray dryer (B-290, Buchi, Switzerland) with drying air flow rate, compressor air pressure, and feed rate set at 473 $\mathrm{L} / \mathrm{h}, 40 \mathrm{~m}^{3} / \mathrm{h}$, and $3 \mathrm{~mL} / \mathrm{min}$, respectively. The physicochemical qualities, particle image morphology, and estimated storage time of $\beta$-carotene and lycopene were determined.

Results. Increased inlet temperatures of spray drying decreased the bulk density, $\beta$-carotene, and lycopene content of spray-dried powders significantly. The color values of dried powders had significant differences in yellowness $\left(\mathrm{b}^{*}\right)$ and chroma, but not lightness $\left(\mathrm{L}^{*}\right)$, redness $\left(\mathrm{a}^{*}\right)$, and hue when the inlet temperature increased from $160^{\circ} \mathrm{C}$ to $180^{\circ} \mathrm{C}$. The maximum reduction of $\beta$ - 
25 carotene and lycopene observed during storage at $55^{\circ} \mathrm{C}$ was $90.88 \%$ and $91.11 \%$ for 33 and 18 26 days. For $\beta$-carotene, the estimated shelf-life (retention of $50 \%$ of $\beta$-carotene) was $9.9,48.4$, and 2791.6 days at $25^{\circ} \mathrm{C}, 10^{\circ} \mathrm{C}$, and $4^{\circ} \mathrm{C}$. The shelf-life of lycopene was 26,176 , and 357 days at $25^{\circ} \mathrm{C}$, $2810^{\circ} \mathrm{C}$, and $4^{\circ} \mathrm{C}$, respectively. HBCD could be potentially used as an encapsulating agent in spraydried Gac aril, but the shelf-life of $\beta$-carotene and lycopene needs to be improved to be useful as 30 a food ingredient.

\section{Introduction}

Fresh Gac fruit (Momordica cochinchinensis Spreng) can be consumed for aril and pulp parts and

34 is rich in carotenoids, mainly $\beta$-carotene and lycopene. Pulp, peel, and aril have significant differences in the quantity of lycopene, beta-carotene, and lutein (Kubola and Siriamornpun 2011). From the whole fruit, Gac aril is the most used and studied source of carotenoids ( $\alpha$-carotene, $\beta$ carotene, cis-lycopene, trans-lycopene, lutein, zeaxanthin, cryptoxanthin), vitamin E, vitamin C, and essential fatty acids (omega-3 and omega-6) (Nhung et al., 2010; Kha et al., 2013; Kubola et al., 2013; Oanh et al., 2017). The quantity of beta-carotene and lycopene in Gac aril is five times higher than in tomatoes (Vuong et al., 2006). However, beta-carotene and lycopene are prone to oxidation, thereby reducing their antioxidant activity. For use as a food ingredient, spray drying (Kha et al., 2010; Cao-Hoang et al., 2011b; Chuyen et al., 2019) and freeze-drying (Tran et al., 2008; Kumkong et al., 2015) have been used to reduce losses of $\beta$-carotene and lycopene.

44 Compared to freeze-drying, spray drying is more economically feasible and more widely used for 45 encapsulating $\beta$-carotene and lycopene. Different encapsulating materials reported include whey protein concentrate and gum Arabic (Chuyen et al., 2019), polylactic acid with and without tween

4780 (Cao-Hoang et al., 2011a,b), and cyclodextrin (Polyakov et al., 2004). With the benefit of 
48 cyclodextrin's cyclic structure, the sensitive fat-soluble compounds can be trapped inside the 49 dextrin chain, thereby protecting them from oxidation. One of the commercial drying aids is the 50 highly branched cyclodextrin (HBCD), a highly water-soluble cyclodextrin with a molecular 51 weight of $462 \mathrm{kDa}$ and capable of bonding hydrophobic compounds (Kaneo et al., 2014). HBCD 52 has been used for pharmaceutical research to stabilize amphotericin B (Kaneo et al., 2014). Spray53 dried powder for use in inhalers has been produced using HBCD with different active drugs such 54 as 1-naphthoic acid and rifampicin (Kadota et al., 2015a), theophylline and clotrimazole (Kodata et al., 2015b), and pyrazinamide and rifampicin (Tse et al., 2018). Kagami et al. (2003) investigated the oxidative stability of spray-dried fish oil having maltodextrin or HBCD and sodium caseinate as wall materials. Results showed that the oil load level and the type of dextrin strongly affected the inner structure, and the ratio of the oil to dextrin affected the surface of the microcapsule. Park et al. (2019) compared carnosic acid solubility in rosemary complexed with cycloamylose, branched dextrin, $\beta$-cyclodextrin, or maltodextrin. Carnosic acid microcapsules produced with cycloamylose had the highest solubility, antioxidant activity, and antimicrobial activity. HBCD has been applied in spray drying of medical or food applications. However, no report of HBCD has been published in the spray drying of Gac. In addition to the lack of studies using HBCD in spray drying of Gac aril, there is a paucity of relevant information about the shelf life of $\beta$-carotene and lycopene in Gac powders.

Therefore, the encapsulation of $\beta$-carotene and lycopene of Gac aril with HBCD by spray drying 67 at different inlet temperatures were compared in this study. The shelf-life study and estimated storage time of $\beta$-carotene and lycopene were calculated at different storage temperatures.

69

\section{Materials \& Methods}

\section{Overview of the experimental program}


72 Figure 1 shows a schematic diagram of spray-dried Gac aril powder's production. Briefly, the Gac

73 aril was separated from the whole Gac and kept frozen. The Gac aril was mixed with highly

74 branched cyclodextrin as a drying aid at 5\% for spray drying. The condition of inlet temperatures

$75\left(140^{\circ} \mathrm{C}, 160^{\circ} \mathrm{C}\right.$, and $\left.180^{\circ} \mathrm{C}\right)$ of spray drying was varied. The spray-dried Gac aril samples were

76 stored at different temperatures $\left(30^{\circ} \mathrm{C}, 45^{\circ} \mathrm{C}\right.$, and $\left.55^{\circ} \mathrm{C}\right)$ for 45 days. The spray-dried Gac aril

77 samples were then analyzed for physicochemical properties, carotenoid content, and

78 morphological analysis. The results of $\beta$-carotene and lycopene were calculated for the spray-dried

79 Gac aril's shelf-life period.

80 Purchase of Gac fruit and Custer Dextrin ${ }^{\mathrm{TM}}$

81 Fresh Gac fruit was purchased from a local market in Bangkok, Thailand. Highly branched

82 cyclodextrin (HBCD, Custer Dextrin ${ }^{\mathrm{TM}}$ ) was obtained from a reputable commercial outlet in 83 Bangkok, Thailand.

\section{Fresh Gac fruit aril preparation}

85 Gac fruit's surface was cleaned with tap water and dried at room temperature. The preparation 86 technique was followed by Kumkong et al. (2015). The whole fruit was cut and separated from 87 the red aril containing the seeds. The seeds were removed entirely, and the viscous aril pulp was 88 filtered through the cheesecloth. The viscous aril juice was packed in a polypropylene bag and 89 kept frozen at $-20^{\circ} \mathrm{C}$ until use. The frozen aril was thawed at room temperature for further 90 experiments.

\section{Production of spray-dried Gac aril powder}

92 The preparation of spray-dried Gac aril was modified the method of Kha et al. (2010). For each 93 experimental run, the red viscous aril juice $(500 \mathrm{~g})$ was blended in distilled water $(2.5 \mathrm{~L})$ in a 94 ratio of 1:5. The resulting juice was centrifuged using a high-speed centrifuge (Sorval, Dupont, 
95 U.S.A.) at $8,000 \mathrm{~g}$ at $20^{\circ} \mathrm{C}$ for $15 \mathrm{~min}$ and filtered twice using a No.1 Watchman filtered paper.

96 Next, the filtered Gac aril juice was then concentrated by a rotary evaporator (R-200, Buchi,

97 Switzerland) until the soluble solid was $15^{\circ}$ Brix. The concentrated Gac aril juice was mixed with

$98 \mathrm{HBCD}$ at $5 \%(\mathrm{w} / \mathrm{v})$ until the HBCD was completely dissolved. The mixture was dried using a

99 spray dryer (B-290, Buchi, Switzerland). Three inlet temperatures $\left(140^{\circ} \mathrm{C}, 160^{\circ} \mathrm{C}\right.$, and $\left.180^{\circ} \mathrm{C}\right)$ of

100 drying air flow rate, compressor air pressure, and feed rate were set at $473 \mathrm{~L} / \mathrm{h}, 40 \mathrm{~m} / \mathrm{h}$, and 3

$101 \mathrm{~mL} / \mathrm{min}$, respectively. After the drying process, the Gac aril powder was collected and packed in

102 a zip-lock bag wrapped with aluminum foil and immediately stored in a desiccator at room

103 temperature. The spray-drying process of Gac aril was carried out in duplicate.

\section{Analysis}

\section{Moisture content}

106 The moisture content of Gac samples (2 g) was determined by the oven drying method at $105^{\circ} \mathrm{C}$

107 (AOAC, 2000).

108 Water activity $\left(\mathbf{a}_{\mathbf{w}}\right)$

109 The spray-dried powders' water activity was measured using a water activity meter (AquaLab,

110 Decagon Devices, USA). The water activity meter was calibrated with a saturated salt standard

111 before use. Measurements were performed at room temperature.

$112 \mathbf{p H}$

$113 \mathrm{pH}$ was determined by blending $1 \mathrm{~g}$ powder with $5 \mathrm{~mL}$ of deionized water at room temperature

114 and using a $\mathrm{pH}$ meter (Oaklon, USA).

\section{Color}

116 The color of Gac aril powders was measured in powder and solution. The Gac fruit powder

117 sample was dissolved with deionized water at 1:5 (w/v) and stirred until the powder was 
118 completely soluble. The Gac powder or solution was poured into a glass container approximately

119 half cup and measured using a color meter (C-10, Minolta, Japan) calibrated with a standard

120 white tile. The results were expressed as Hunter color values of $L^{*}, a^{*}$, and $b^{*}$, where $L^{*}$ was

121 used to denote lightness $(0-100),+a^{*}$ redness and $-a^{*}$ greenness, and $+\mathrm{b}^{*}$ yellowness and $-\mathrm{b}^{*}$

122 blueness. Hunter values of the samples for each treatment method were measured in triplicate.

123 Water solubility index (WSI)

124 The water solubility index of the spray-dried Gac powders was analyzed by Anderson et al.

125 (1969). The Gac aril powder (2.5 g) was added to distilled water $(30 \mathrm{~mL})$ in a $40 \mathrm{~mL}$ centrifuge 126 tube, mixed well, incubated in an incubator at $37^{\circ} \mathrm{C}$ for $30 \mathrm{~min}$, and then centrifuged for $20 \mathrm{~min}$ 127 at 10,000 rpm in a high-speed centrifuge (Sorval, Dupont, USA). The supernatant was dried in 128 an oven dryer at $103 \pm 2{ }^{\circ} \mathrm{C}$. The WSI (\%) was calculated as the percentage of dried supernatant 129 with respect to the original $2.5 \mathrm{~g} \mathrm{Gac}$ aril sample.

\section{Bulk density}

131 Bulk density was determined by Goula et al. (2004). Gac aril powder (2 g) was added into an

132 empty $10 \mathrm{~mL}$ graduated cylinder and vortexed on a vortex mixer for $1 \mathrm{~min}$. The bulk density 133 value $(\mathrm{g} / \mathrm{mL})$ was calculated by the powder's mass ratio to the volume occupied in the cylinder.

\section{Determination of total carotenoid content}

135 The total carotenoid content of Gac aril powder was analyzed by the modified method of 136 Kaisangsri et al. (2016). The Gac powder sample of $80 \mathrm{mg}$ and $4 \mathrm{~mL}$ of dimethyl sulfoxide 137 (DMSO) was added to the glass tube, incubated at $75^{\circ} \mathrm{C}$ in a water bath for $50 \mathrm{~min}$, and cooled to 138 room temperature. After that, the $4 \mathrm{~mL}$-hexane, containing $0.1 \mathrm{~g} / 100 \mathrm{~mL}$ butylated 139 hydroxytoluene, was added, vortexed for $10 \mathrm{~s}$, and left for $30 \mathrm{~min}$. A few (2-3) drops of ethanol 140 were added to precipitate any protein in the hexane phase. The top layer was removed into 
141 another tube using a glass pipette. Approximately $0.5 \mathrm{~g}$ of anhydrous sodium sulfate was added

142 to the tube and let stand for 15 min to absorb any residual water in the $\mathrm{n}$-hexane solution. Total

143 carotenoid concentration in the hexane solution was then measured absorbance at $450 \mathrm{~nm}$

144 wavelength using a UV-VIS spectrophotometer (UV-1601, Shimadzu, Japan). Total carotenoid

145 concentration was calculated with a standard curve using the known concentrations of $\beta$-carotene

$146(0-1 \mathrm{mg} / \mathrm{L})$ in hexane. Triplicate samples were analyzed.

147 Determination of $\beta$-carotene and lycopene content by HPLC

$148 \beta$-carotene and lycopene contents were measured using Ishida et al. (2004) with some

149 modification. Gac aril powder ( $1 \mathrm{~g})$ was extracted with $5 \mathrm{~mL}$ of $40 \%$ methyl-tert-butyl ether

150 (MTBE), 50\% methanol, and 10\% ethyl acetate (v/v) for $1 \mathrm{hr}$. The extracts were passed through 151 a $0.45-\mathrm{mm}$ poly(tetrafluoroethylene) filter. Throughout these procedures, care was taken to keep 152 samples ice-cold and protect them from light exposure. $\beta$-carotene and lycopene content were 153 quantified using a reversed-phase HPLC system, consisting of Agilent 1200 series, Diode-Array 154 Detector, auto-injector, and column temperature regulator. Separations were accomplished using 155 an analytical polymeric Verticep ${ }^{\mathrm{tm}}$ Bio C30 column $(250 \times 4.6-\mathrm{mm})$. The C30 column was then 156 conditioned with elution solvent at a $1 \mathrm{~mL} / \mathrm{min}$ flow rate for $50 \mathrm{~min}$. Carotenoids were separated 157 using an isocratic mobile phase of 40\% methyl-tert-butyl ether (MTBE), 50\% methanol, and $15810 \%$ ethyl acetate $(\mathrm{v} / \mathrm{v})$. Injection volumes ranged from $10 \mu \mathrm{L}$. The column temperature was 159 maintained at $28^{\circ} \mathrm{C}$. Samples were detected at $450 \mathrm{~nm}$.

\section{Morphological analysis}

161 Gac aril powders' surface morphology was evaluated using scanning electron microscopy (JSM-

$1627600 \mathrm{~F}$, Jeol, Tokyo, Japan). The samples were briefly coated with $5 \mathrm{~nm}$ gold under vacuum by a 163 fine auto coater (JSM-7600F, Jeol, Tokyo, Japan), and the powder morphology was carried out at 
164 an accelerating voltage of $1.0 \mathrm{kV}$ by the scanning electron microscopy. The digital images were 165 captured with magnifications of $1000 \mathrm{X}-5000 \mathrm{X}$.

166 Determination of shelf-life of $\beta$-carotene and lycopene of spray-dried Gac aril powders

167 Gac aril powder $(10 \mathrm{mg})$ produced with an inlet temperature of $160^{\circ} \mathrm{C}$ was kept in closed vials.

168 The vial samples were then stored at different temperatures of $30^{\circ} \mathrm{C}, 45^{\circ} \mathrm{C}$, and $55^{\circ} \mathrm{C}$ for 45 days.

169 Triplicate samples were periodically withdrawn during the storage to measure $\beta$-carotene and 170 lycopene contents by HPLC, as described previously.

$171 \beta$-carotene and lycopene content of storage at $45^{\circ} \mathrm{C}$ and $55^{\circ} \mathrm{C}$ was used to calculate storage study

172 by accelerated shelf-life tests (ASLT), using the following equation (ASTM, 1980; Mizrahi, 173 2004). Temperature coefficient $Q_{10}$ and $Q_{1}$ are the reaction rate for a different temperature of 10 174 and $1^{\circ} \mathrm{C}$, respectively, as illustrated in equation 1 and equation 2 . The storage time of $\beta$-carotene 175 and lycopene with a $50 \%$ reduction at $25^{\circ} \mathrm{C}, 10^{\circ} \mathrm{C}$, and $4{ }^{\circ} \mathrm{C}$ were also calculated by equation 3 .

$$
\begin{aligned}
& Q_{10}=\frac{\theta_{s(T)}}{\theta_{s(T+10)}} \\
& Q_{1}=Q_{10}^{0.1} \\
& Q_{1}^{\Delta T}=\frac{\theta_{s(T)}}{\theta_{s(T+\Delta T)}}
\end{aligned}
$$

179 Where $\Theta_{\mathrm{s}(\mathrm{T})}$ is the storage time at the temperature $\mathrm{T}$ (days), $\Theta_{\mathrm{s}(\mathrm{T}+10)}$ is the storage time at the 180 temperature $\mathrm{T}+10$ (days), and $\Delta \mathrm{T}$ is the difference in ${ }^{\circ} \mathrm{C}$ between the predicted temperature and 181 accelerated temperature.

183 Statistical analysis

184 All analytical measurements were carried out in triplicate. The results were calculated and reported 185 in the mean value and standard deviation. The statistical differences were compared to the mean values using Duncan's multiple range test of SPSS for Windows software version 25.0. 


\section{Results}

189 Effect of inlet drying temperature on the physicochemical properties of Gac aril juice powder

190 The spray-dried Gac aril juice powders produced at different inlet temperatures $\left(140^{\circ} \mathrm{C}, 160^{\circ} \mathrm{C}\right.$, 191 and $180^{\circ} \mathrm{C}$ ) showed slightly different physicochemical characteristics, as seen in Table 1 . The 192 moisture contents ranged from $9.89-10.86 \%$. When the inlet temperature was changed from $140^{\circ} \mathrm{C}$ 193 to $160^{\circ} \mathrm{C}$, powders' water activity values decreased from 0.61 to 0.52 . No significant change in $\mathrm{a}_{\mathrm{w}}$ 194 was obtained when the temperature was increased to $180^{\circ} \mathrm{C}$. The Gac aril solution's $\mathrm{pH}$ was in 195 acidic $\mathrm{pH}$ (5.53-5.63). For bulk density, the increased inlet temperature significantly reduced the 196 density. The WSI relates to the solubility of dried powder in water. In this study, the aril powder 197 spray dried with an inlet temperature of $160^{\circ} \mathrm{C}$ had a different result of WSI compared to those of 198 spray-dried aril powders using inlet temperatures of $140^{\circ} \mathrm{C}$ and $180^{\circ} \mathrm{C}$. Spray drying at $140^{\circ} \mathrm{C}$ may 199 not be microbiologically stable as the $\mathrm{a}_{\mathrm{w}}$ was higher than 0.60 and might cause aggregation during 200 storage.

201 Total carotenoid compounds (TCC) of $\beta$-carotene and lycopene significantly decreased at 202 increased inlet drying temperature (Table 1). Increased inlet temperatures showed significantly 203 affected color parameters (Table 2). When reconstituted in water, the solution of Gac aril yielded 204 no significant differences in the lightness $\left(\mathrm{L}^{*}\right)$, redness $\left(\mathrm{a}^{*}\right)$, and hue (Table 3$)$. The yellowness

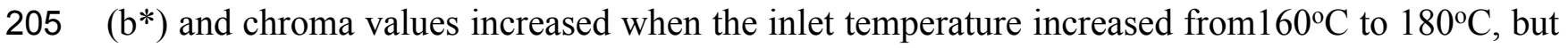
206 not from $140^{\circ} \mathrm{C}$ to $160^{\circ} \mathrm{C}$. The decreased $\mathrm{L}^{*}$ and increased $\mathrm{b}^{*}$ could be affected by high drying 207 temperature.

208 Morphology of spray-dried Gac aril powders by SEM

209 The morphology of the dried particles showed the cluster of spherical particles with a mixed size 
210 of greater than $10 \mu \mathrm{m}$ when the increased temperature was used (Figure 2). The scar remaining 211 on the particle resulted from the detached particle. No broken particles were seen in all spray-dried 212 samples.

213 Effect of storage temperature and time on the reduction of $\beta$-carotene and lycopene in 214 spray-dried Gac aril powder

215 The concentration of $\beta$-carotene and lycopene content of spray-dried Gac aril powders reduced 216 as affected by the increasing storage temperature and time. At $30^{\circ} \mathrm{C}, \beta$-carotene and lycopene 217 were reduced from $1.403 \pm 0.019$ and $0.225 \pm 0.004$ to $0.117 \pm 0.014$ and $0.033 \pm 0.004 \mathrm{mg} / \mathrm{g}$ in 218 samples kept for 42 and 24 days, respectively (Supplemental File 1). Increased storage 219 temperature shortened the shelf life of $\beta$-carotene and lycopene. The $\beta$-carotene reductions were 220 90.887 and $89.950 \%$ at 33 and 21 days, and the lycopene reductions were 65.778 and $91.111 \%$ at 22121 and 18 days when kept at $45^{\circ} \mathrm{C}$ and $55^{\circ} \mathrm{C}$, respectively (Figure 3A-3B, Figure 4A-4B). The 222 reduction of $\beta$-carotene and lycopene was approximately $12 \%$ and $10 \%$ between $18-21$ days of 223 storage, respectively (Figure $3 \mathrm{~A}$ and Figure $4 \mathrm{~A}$ ). The $\mathrm{Q}_{10}$ for the reduction of $\beta$-carotene and 224 lycopene were 1.112 and 1.135 (Table 4).

225 The estimation of $\beta$-carotene and lycopene storage times if kept at $25^{\circ} \mathrm{C}, 10^{\circ} \mathrm{C}$, and $4^{\circ} \mathrm{C}$ is in 226 Table 5. The regression equations from Figures $3 \mathrm{~A}-3 \mathrm{~B}$ and Figures $4 \mathrm{~A}-4 \mathrm{~B}$, assuming a 50\% loss 227 of $\beta$-carotene or lycopene, were used for this calculation. Results showed that if the spray-dried 228 229 230 encapsulated with the Custer Dextrin ${ }^{\mathrm{TM}}$.

\section{Discussion}


233 Spray drying has been used to encapsulate Gac's carotenoid compounds (Chuyen et al., 2019; Cao-

234 Hoang et al., 2011a,b; Kha et al., 2010; Tran et al., 2008). Several factors affecting the degradation

235 of $\beta$-carotene and lycopene, such as the type and concentration of wall materials and inlet

236 temperatures of spray drying, have been studied. The wall material plays a vital role in protecting

237 sensitive carotenoid compounds. Different types of wall material used were a mixture of whey

238 protein concentrate and gum Arabic (Chuyen et al., 2019) and polylactic acid (Cao-Hoang et al.,

239 2011a,b), and maltodextrin (Kha et al., 2014; Kha et al., 2010). The HBCD was first reported to

240 encapsulate carotenoid-rich oil lycopene at the lowest concentration of $5 \%$. With differences in

241 experimental factors studied, the expected results of spray-dried Gac powders were also different.

242 Results of moisture content and $\mathrm{a}_{\mathrm{w}}$ (Table 1) were different from Chuyen et al. (2019) that the

243 spray-dried carotenoid-rich oil from Gac peel with a mixture of whey protein concentrate and

244 Arabic gum powder had the moisture content of 3.0-5.2\% and $\mathrm{a}_{\mathrm{w}}$ of $0.32-0.45$ when applied inlet

245 temperature of $160^{\circ} \mathrm{C}$ and $180^{\circ} \mathrm{C}$, respectively. The characteristics of spray-dried Gac aril with $5 \%$

246 HBCD were mostly lower than the results of Kha et al. (2010) that applied inlet temperatures from

$247120^{\circ} \mathrm{C}$ to $200^{\circ} \mathrm{C}$ and maltodextrin 10,20 , and $30 \%$ to Gac aril, except for the moisture content and

248 WSI. The spray-dried Gac had moisture content, $\mathrm{a}_{\mathrm{w}}, \mathrm{pH}$, bulk density, and WSI ranged from 3.88-

$2495.29 \%, 0.45-0.50,4.12-4.45,0.66-0.78 \mathrm{~g} / \mathrm{ml}$, and $37.13-37.62 \%$ (Kha et al., 2010).

250 The stability of color of Gac's $\beta$-carotene and lycopene having the red-orange shade has become

251 of interest for replacing the synthetic color for food products (Selig et al., 2018; Kumkong et al.,

252 2020); therefore, the protection of these sensitive compounds from processing has become

253 necessary. The color values of encapsulated spray-dried Gac with HBCD were similar to the spray-

254 dried Gac with maltodextrin if the inlet temperatures were not greater than $180^{\circ} \mathrm{C}$ (Kha et al., 
255 2010). However, with different drying, the spray-dried Gac aril's color yielded a higher chroma 256 value than that of freeze-dried Gac aril (Kumkong et al., 2020).

257 The differences in drying agents and inlet temperatures influence the reduction of carotenoid 258 content of spray-dried Gac aril. This study showed total carotenoid content of $0.819,0.716$, and $2590.640 \mathrm{mg} \beta$-carotene/g when used inlet temperature of $140^{\circ} \mathrm{C}, 160^{\circ} \mathrm{C}$, and $180^{\circ} \mathrm{C}$ (Table 1 ). The 260 values were lower than the study of Kha et al. (2010) that showed the total carotenoid content of $2611.95 \mathrm{mg} / \mathrm{g}$ when used at the inlet temperature of $120^{\circ} \mathrm{C}$ and maltodextrin $10 \%(\mathrm{w} / \mathrm{v})$. Tran et al. 262 (2008) reported that the spray-dried Gac aril had carotenoid content of $379.7 \mu \mathrm{g} / \mathrm{g}$ powder with 263 almost no $\beta$-carotene when used the inlet temperature $200^{\circ} \mathrm{C}$. The study confirmed that the 264 reduction of $\beta$-carotene and lycopene occurred during the spray drying. In this study, the 265 concentration of HBCD was used only at 5\%. However, it is worth to study further the effect of 266 increased concentration of $\mathrm{HBCD}$ on the retention of Gac aril carotenoid.

267 The scanning electron microscope can be used to observe the microencapsulated of Gac aril 268 carotenoid. The use of HBCD encapsulated Gac carotenoid displayed mostly round and smooth 269 surface particles (Figure 2). Compared to Chuyen et al. (2019), which displayed the SEM pictures 270 of whey protein concentrated and Arabic gum wall material encapsulated with Gac carotenoids, 271 the shape and size of particles were quite different. The spray-dried powder with different wall 272 materials influences particles' integrity and affects total carotenoid content loss during drying 273 (Chuyen et al., 2019; Kha et al., 2010).

274 The $\beta$-carotene and lycopene are sensitive carotenoid compounds that can be degraded by 275 pretreatment (Tran et al., 2008; Kha et al., 2014), light (Nhung et al., 2010), high temperature of 276 the process (Tran et al., 2008; Kha et al., 2010), oxygen (Nhung et al., 2010; Cao-Hoang et al., 277 2011) and storage time (Nhung et al., 2010; Chuyen et al., 2019). Results showed that the shelf- 
278 life of $\beta$-carotene and lycopene was affected by increased temperature to $10^{\circ} \mathrm{C}$ and $25^{\circ} \mathrm{C}$ (Table 5).

279 From the calculation, the degradation of $\beta$-carotene showed more pronounced than that of lycopene

280 shown in Figure 3A-3B and Figure 4A-4B. The retention of $\beta$-carotene of this study differs from

281 the study of Chuyen et al. (2019), who reported the total carotenoid retention of the encapsulated

282 powder of Gac peel oil stored at $5^{\circ} \mathrm{C}$ and $20^{\circ} \mathrm{C}$ for 6 months was $65.3 \%$ and $41.5 \%$, respectively,

283 despite differences in wall material and spray-drying condition. The structure of these two

284 compounds is different. $\beta$-carotene consists of isoprene units having beta-rings at the ends. Once

285 the $\beta$-carotene molecule is hydrolyzed, the two retinal molecules designated as vitamin A are

286 formed, and lycopene is a polar acyclic carotenoid. These two compounds can be undergone

287 oxidations. Cao-Huang et al. (2011) illustrated the chemical degradation pathway of both $\beta$ -

288 carotene to form compounds of $\beta$-ionone, 5,6-epoxy- $\beta$-ionone, dihydro actinidiolide, and $\beta$ -

289 cyclocitral. The shelf-life of $\beta$-carotene and lycopene in this study were different and not

290 comparable from other research works due to several factors, such as different drying agents used,

291 spray drying conditions, storage condition, and analysis method. Cao-Huang et al. (2011) stated

292 that the lycopene was more sensitive to oxidation than $\beta$-carotene. The degradation rate of

293 lycopene prepared with PLA and without PLA was $11 \mathrm{mM}$ and $7 \mathrm{mM}$ after $24 \mathrm{~h}$ of oxidation.

294 Chuyen et al. (2019) reported the low retention of total carotenoids in spray-dried Gac oil powder

295 encapsulated with whey protein concentrate and Arabic gum was $65.3 \%$ and $41.5 \%$ after kept for 2966 months at $5^{\circ} \mathrm{C}$ and $20^{\circ} \mathrm{C}$.

297

298 Conclusions

299

300 The spray-dried Gac aril powders with $5 \%$ HBCD produced with different inlet temperatures

$301\left(140^{\circ} \mathrm{C}, 160^{\circ} \mathrm{C}\right.$, and $\left.180^{\circ} \mathrm{C}\right)$ showed slightly different physicochemical characteristics (moisture 
302 content, $\mathrm{a}_{\mathrm{w}}$, bulk density, and WSI). Drying with HBCD enclosed the carotenoids in the spherical

303 particles with a mixed size greater than $10 \mu \mathrm{m}$. The use of HBCD and spray drying at the inlet

304 temperature of $160^{\circ} \mathrm{C}$ showed potential for encapsulating the sensitive compounds of $\beta$-carotene

305 and lycopene. The shelf-life study confirmed that the low-temperature storage at $4^{\circ} \mathrm{C}$ of the spray-

306 dried aril powders with 50\% reduction $\beta$-carotene and lycopene content was 91 and 357 days,

307 respectively.

308

309

\section{Acknowledgements}

310

311 We would like to thank Mr. Keerati Thamapan for performing statistical analysis and

312 calculation.

313

314 References

315

316

AOAC 2000. Official method of analytical of AOAC International (Eighteenth ed.) Maryland,

317 USA.

318

319

320

321

322

ASTM 1980. Standard test method for shelf-life Testing, standard guide for accelerated aging of sterile barrier systems for medical device. ASTM International, West Conshohocken, PA.

Anderson R A, Conwau H F, Pferifer V F, Griffin J R. 1969. Gelatinization of corn grits by roll and extrusion cooking. Cereal Science Today 14(1): 4-11

Cao-Hoang L, Fougére R, Waché Y. 2011 a Increase instability and change in supramolecular $\underline{\text { structure of beta-carotene through encapsulation into polylactic acid nanoparticles. }}$ Food Chemistry 124(1): 42-49 
gâc (Momordica cochinchinensis) towards cooxidation-Protective effect of lycopene on $\beta$-carotene. Food Research International 44: 2252-2257

329

330

331

332

333

334

335

336

337

338

339

340

341

342

343

344

345

346

Chuyen H V, Roach P D, Golding J B, Parks S E, Nguyen M H. 2019. Encapsulation of carotenoid rich oil from Gac peel: Optimisation of the encapsulating process using a spray drier and the storage stability encapsulated powder. Powder Technology 344:373-379

Goula A M, Adamopoulos K G, Kazakis N A. 2004. Influence of spray drying condition on tomato power properties. Drying Technology 22 (5): 1129-1151

Kagami Y, Sugimura S, Fujishima N, Matsuda K, Kometani T, Matsumura Y. 2003. Oxidative Stability, Structure, and Physical Characteristics of Microcapsules Formed by Spray Drying of Fish Oil with Protein and Dextrin Wall Materials. Journal of Food Science 68: 2248-2255

Kadota K, Nishimura T, Hotta D, Tozuka Y. 2015a Preparation of composite particles of hydrophilic or hydrophobic drug with highly branched cyclic dextrin via spray drying for dry powder inhalers. Powder Technology 283:16-25

Kadota K, Senda A, Ito T, Tozuka Y. 2015b Feasibility of highly branched cyclic dextrin as an excipient matrix in dry powder inhalers. European Journal of Pharmaceutical Sciences 79:79-86

\section{Kaisangsri N, Kowalski R J, Wijesekara I, Kerdchoechuen O, Laohakunjit N, Ganjyal G} M. 2016. Carrot pomace enhances the expansion and nutritional quality of corn starch extrudates. LWT - Food Science and Technology 68: 391-399 
347 Kaneo Y, Taguchi K, Tanaka T, Yamamoto S. 2014. Nanoparticles of hydrophobized

348

349

350

351

352

353

354

355

356

357

358

359

360

361

362

363

364

365

366

367

368

$\underline{\text { cluster dextrin as biodegradable drug carriers: solubilization and encapsulation of }}$ amphotericin B. Journal of Drug Delivery Science and Technology 24(4): 344-351

Kha T C, Nguyen M H, Roach P D. 2010. Effect of spray drying conditions on the physicochemical and antioxidant properties of the Gac (Momordica cochinchinensis) fruit aril powder. Journal of Food Engineering 98: 385-392

Kha T C, Nguyen M H, Roach P D, Stathopoulos C E. 2014. Microcapsulation of Gac oil: optimization of spray drying conditions using response surface methodology. Powder Technology 264: 298-309

Kubola J, Meeso N, Siriamornpun S. 2013. Lycopene and beta carotene concentration in aril oil of gac (Momordica cochinchinensis Spreng) as influenced by aril-drying process and solvents extraction. Food Research International 50(2): 664-669

Kubola J, Siriamornpun S. 2011. Phytochemicals and antioxidant activity of different fruit fractions (peel, pulp, aril and seed) of Thai Gac (Momordica cochinchinensis Spreng). Food Chemistry 127:1138-1145

Kumkong N, Thumthanaruk B, Banjongsinsiri P, 2015. Factors affecting stability of lycopene and $\beta$-carotene from Gac aril powder by freeze drying. Journal of Food Science and Agricultural Technology 3(1):1-6

Kumkong N, Banjongsinsiri P, Laohakunjit N, Vatanyoopaisarn S, Thumthanaruk B, 2020. Influence of natural colour blends of freeze-dried Gac aril and pulp on the quality of whey protein-mixed gelatin-based chewables. Heliyon 6: e05817

Ishida B K, Turner C, Chapman M H, McKeon T A. 2004. Fatty acid and carotenoid 
composition of Gac. (Momordica cochinchinensis Spreng) fruit. Journal of Agricultural and

370 Food Chemistry 52(2): 274-279

371 Mizrahi S. 2004. Understanding and Measuring the Shelf-life of Food. F\&N Press., Westport.

372 Nhung D T T, Bung P N, Ha N T, Phong T K. 2010 Changes in lycopene and beta carotene contents in aril and oil of gac fruit during storage. Food Chemistry 121: 326-331

Oanh H T, Nhung H T, Tuyen N D, Van T K, Trung T H, Ha H M. 2017 Extraction of lycopene from Gac fruit (Momordica cochinchinensis Spreng) and preparation of nanolycopene. Vietnam Journal of Chemistry, International Edition 55(6): 761-766

Polyakov N E, Leshina T V, Konovalova T A, Hand E O, Kispert L D. 2004. Inclusion complexes of carotenoids with cyclodextrins: 1H NMR, EPR and optical studies. Free Radical Biology and Medicine 36(7): 872-880

Selig M J, Mehrad B, Zamani H, Kierulf A, Licker J. 2018. Distribution of oil solubilized $\beta$ carotene in stabilized locust bean gum powders for the delivery of orange colorant to food products. Food Hydrocolloids 84:34-37

Tran T H, Nguyen M H, Zabaras D, Vu L T T. 2008. Process development of Gac powder by using different enzymes and drying techniques. Journal of Food Engineering $85(3): 359-365$

Tse Y J, Kadota K, Hirata Y, Taniguchi M, Uchiyama H, Tozuka Y. 2018. Characterization of $\underline{\text { matrix embedded formulations for combination spray-dried particles comprising }}$ pyrazinamide and rifampicin. Journal of Drug Delivery Science and Technology 48: 137- 
393 Vuong L T, Franke A A, Custer L J, Murphy S P. 2006. Momordica cochinchinensis Spreng.

$394 \quad$ (gac) fruit carotenoids reevaluated. Journal of Food Composition and Analysis

395 19(6-7): 664-668

396 


\section{Table 1 (on next page)}

Characteristics of spray-dried Gac aril powders

Values are expressed as mean \pm standard deviation $(n=3)$ Numbers with different small superscripts in the same column showed significant differences $(p<0.05)$ ns refers to no significant differences 
1 Table 1: Characteristics of spray-dried Gac aril powders

2

\begin{tabular}{llll}
\hline Sample & $\begin{array}{l}\text { Gac aril powder } \\
\text { dried at } 140^{\circ} \mathrm{C}\end{array}$ & $\begin{array}{l}\text { Gac aril powder } \\
\text { dried at } 160^{\circ} \mathrm{C}\end{array}$ & $\begin{array}{l}\text { Gac aril powder } \\
\text { dried at } 180^{\circ} \mathrm{C}\end{array}$ \\
\hline \multicolumn{1}{c}{ Analysis } & $10.860 \pm 0.630$ & $10.520 \pm 0.480$ & $9.890 \pm 0.550$ \\
Moisture content $^{\mathrm{ns}}(\%)$ & $0.610^{\mathrm{a}} \pm 0.002$ & $0.520^{\mathrm{b}} \pm 0.002$ & $0.520^{\mathrm{b}} \pm 0.002$ \\
$\mathrm{a}_{\mathrm{w}}$ content & $5.630^{\mathrm{a}} \pm 0.008$ & $5.540^{\mathrm{b}} \pm 0.017$ & $5.530^{\mathrm{b}} \pm 0.016$ \\
$\mathrm{pH}$ & $0.630^{\mathrm{a}} \pm 0.006$ & $0.580^{\mathrm{b}} \pm 0.004$ & $0.570^{\mathrm{c}} \pm 0.003$ \\
Bulk density $(\mathrm{g} / \mathrm{mL})$ & $81.200^{\mathrm{b}} \pm 1.316$ & $85.500^{\mathrm{a}} \pm 2.071$ & $81.660^{\mathrm{b}} \pm 1.020$ \\
Water solubility index $(\%)$ & $0.819^{\mathrm{a}} \pm 0.045$ & $0.716^{\mathrm{b}} \pm 0.043$ & $0.640^{\mathrm{b}} \pm 0.050$ \\
Total carotenoid compound & & & \\
$(\mathrm{mg} \beta$-carotene/g) & & $1.217^{\mathrm{b}} \pm 0.017$ & $1.071^{\mathrm{c}} \pm 0.007$ \\
$\beta$-carotene $(\mathrm{mg} / \mathrm{g})$ & $1.403^{\mathrm{a}} \pm 0.019$ & $0.141^{\mathrm{b}} \pm 0.018$ & $0.102^{\mathrm{b}} \pm 0.018$ \\
Lycopene $(\mathrm{mg} / \mathrm{g})$ & $0.225^{\mathrm{a}} \pm 0.004$ & & \\
\hline Van & & &
\end{tabular}

Values are expressed as mean \pm standard deviation $(\mathrm{n}=3)$

Numbers with different small superscripts in the same column showed significant differences $(p<0.05)$

ns refers to no significant differences 


\section{Table 2 (on next page)}

Color of spray-dried Gac aril powders

Values are expressed as mean \pm standard deviation $(n=3)$ Numbers with different small superscripts in the same columns showed significant differences $(p<0.05)$ ns refers to no significant differences 
1 Table 2: Color of spray-dried Gac aril powders

2

\begin{tabular}{lccccc}
\hline Sample & $\mathrm{L}^{*}$ & $\mathrm{a}^{*}$ & $\mathrm{~b}$ & Chroma & hue \\
\hline $\begin{array}{l}\text { Gac dried powder } \\
\text { at } 140^{\circ} \mathrm{C}\end{array}$ & $84.91^{\mathrm{a}} \pm 0.61$ & $10.84^{\mathrm{c}} \pm 0.18$ & $24.23^{\mathrm{c}} \pm 0.40$ & $26.55^{\mathrm{c}} \pm 0.43$ & $65.90^{\mathrm{b}} \pm 0.03$ \\
\hline $\begin{array}{l}\text { Gac dried powder } \\
\text { at } 160^{\circ} \mathrm{C}\end{array}$ & $81.95^{\mathrm{b}} \pm 0.29$ & $12.66^{\mathrm{b}} \pm 0.07$ & $27.40^{\mathrm{b}} \pm 0.15$ & $30.19^{\mathrm{b}} \pm 0.17$ & $65.20^{\mathrm{c}_{ \pm} \pm 0.01}$ \\
\hline $\begin{array}{l}\text { Gac dried powder } \\
\text { at } 180^{\circ} \mathrm{C}\end{array}$ & $80.49^{\mathrm{c}} \pm 0.26$ & $14.02^{\mathrm{a}} \pm 0.07$ & $32.01^{\mathrm{a}} \pm 0.23$ & $34.94^{\mathrm{a}} \pm 0.23$ & $66.35^{\mathrm{a}} \pm 0.04$ \\
\hline
\end{tabular}

3

$4 \quad$ Values are expressed as mean \pm standard deviation $(n=3)$

5 Numbers with different small superscripts in the same columns showed significant differences

$6 \quad(p<0.05)$

7 ns refers to no significant differences

8 


\section{Table 3 (on next page)}

Color of reconstituted Gac aril solutions

Values are expressed as mean \pm standard deviation $(n=3)$ Numbers with different small superscripts in the same column showed significant differences $(p<0.05)$ ns refers to no significant differences 
1 Table 3: Color of reconstituted Gac aril solutions

2

3

\begin{tabular}{|c|c|c|c|c|c|}
\hline Sample & $\mathrm{L}^{* \mathrm{~ns}}$ & $a^{* n s}$ & $\mathrm{~b}$ & Chroma & hue $^{\text {ns }}$ \\
\hline $\begin{array}{l}\text { Gac dried powder } \\
\text { at } 140^{\circ} \mathrm{C} \text { and } \\
\text { solubilized in } \\
\text { water }\end{array}$ & $52.35 \pm 0.10$ & $10.78 \pm 0.26$ & $36.76^{b} \pm 0.39$ & $38.31^{\mathrm{b}} \pm 0.42$ & $73.66 \pm 0.29$ \\
\hline $\begin{array}{l}\text { Gac dried powder } \\
\text { at } 160^{\circ} \mathrm{C} \text { and } \\
\text { solubilized in } \\
\text { water }\end{array}$ & $52.08 \pm 0.07$ & $11.36 \pm 0.28$ & $37.25^{\mathrm{b}} \pm 0.79$ & $38.95^{\mathrm{b}} \pm 0.80$ & $73.04 \pm 0.34$ \\
\hline $\begin{array}{l}\text { Gac dried powder } \\
\text { at } 180^{\circ} \mathrm{C} \text { and } \\
\text { solubilized in } \\
\text { water }\end{array}$ & $52.22 \pm 0.30$ & $11.78 \pm 0.59$ & $40.05^{\mathrm{a}} \pm 1.44$ & $41.74^{\mathrm{a}} \pm 1.55$ & $73.62 \pm 0.24$ \\
\hline \multicolumn{6}{|c|}{$\begin{array}{l}\text { Values are expressed as mean } \pm \text { standard deviation }(\mathrm{n}=3) \\
\text { Numbers with different small superscripts in the same column showed significant } \\
\text { differences }(p<0.05) \\
\text { ns refers to no significant differences }\end{array}$} \\
\hline
\end{tabular}




\section{Table 4 (on next page)}

Shelf life calculation of $\beta$-carotene and lycopene at $45^{\circ} \mathrm{C}$ and $55^{\circ} \mathrm{C}$ 
1 Table 4: Shelf life calculation of $\beta$-carotene and lycopene at $45^{\circ} \mathrm{C}$ and $55^{\circ} \mathrm{C}$

2

\begin{tabular}{|c|c|c|c|}
\hline Compound & $\begin{array}{l}\text { Shelf life } \\
\text { calculation }\end{array}$ & Equation & Results \\
\hline \multirow[t]{4}{*}{$\beta$-carotene } & Storage at $45^{\circ} \mathrm{C}$ & $y=16.157 \ln (x)+30.953$ & $\mathrm{x}=1.179$ days \\
\hline & Storage at $55^{\circ} \mathrm{C}$ & $\mathrm{y}=17.209 \ln (\mathrm{x})+43.004$ & $\mathrm{x}=0.407$ days \\
\hline & $Q_{10}$ & $=\frac{\theta_{s(45)}}{\theta_{s(55)}}$ & $=\frac{1.179}{0.407}=2.897$ \\
\hline & $Q_{1}$ & $=Q_{10}^{0.1}$ & $=2.897^{0.1}=1.112$ \\
\hline
\end{tabular}

\begin{tabular}{cccc}
\hline Lycopene & $\begin{array}{c}\text { Storage at } 45^{\circ} \mathrm{C} \\
\text { Storage at } 55^{\circ} \mathrm{C}\end{array}$ & $\begin{array}{c}\mathrm{y}=11.157 \ln (\mathrm{X})+26.708 \\
Q_{10}=16.290 \ln (\mathrm{X})+40.423\end{array}$ & $\begin{array}{c}\mathrm{X}=2.008 \text { days } \\
\mathrm{X}=0.590 \text { days }\end{array}$ \\
& $=\frac{\theta_{s(45)}}{\theta_{s(55)}}$ & $=\frac{2.008}{0.590}=3.539$ \\
& $=Q_{10}^{0.1}$ & $=3.539^{0.1}=1.135$ \\
\hline
\end{tabular}




\section{Table 5 (on next page)}

Estimation of shelf life of $\beta$-carotene and lycopene at $25^{\circ} \mathrm{C}, 10^{\circ} \mathrm{C}$, and $4^{\circ} \mathrm{C}$ 
1 Table 5: Estimation of shelf life of $\beta$-carotene and lycopene at $25^{\circ} \mathrm{C}, 10^{\circ} \mathrm{C}$, and $4^{\circ} \mathrm{C}$

2

3

\begin{tabular}{|c|c|c|c|}
\hline Criteria & $\begin{array}{l}\text { Shelf-life } \\
\text { calculation }\end{array}$ & Equation & Result $\left(\theta_{s}\right)$ (day) \\
\hline \multirow[t]{3}{*}{$\begin{array}{l}\text { With } 50 \% \\
\text { reduction } \\
\text { of } \beta \text {-carotene }\end{array}$} & at $25^{\circ} \mathrm{C}$ & $Q_{1}^{45-25}=\frac{\theta_{s(25)}}{\theta_{s(45)}}$ & $\begin{array}{c}1.112^{20}=\frac{\theta_{s(25)}}{1.179} \\
\theta_{s(25)}=9.854 \text { days }\end{array}$ \\
\hline & at $10^{\circ} \mathrm{C}$ & $\mathrm{Q}_{1}^{45-10}=\frac{\theta_{\mathrm{s}(10)}}{\theta_{\mathrm{s}(45)}}$ & $\begin{array}{c}1.112^{35}=\frac{\theta_{s(10)}}{1.179} \\
\theta_{s(10)}=48.437 \text { days }\end{array}$ \\
\hline & at $4^{\circ} \mathrm{C}$ & $Q_{1}^{45-4}=\frac{\theta_{s(4)}}{\theta_{s(45)}}$ & $\begin{array}{c}1.112^{41}=\frac{\theta_{s(4)}}{1.179} \\
\theta_{s(4)}=91.582 \text { days }\end{array}$ \\
\hline \multirow[t]{3}{*}{$\begin{array}{l}\text { With } 50 \% \\
\text { reduction } \\
\text { of lycopene }\end{array}$} & at $25^{\circ} \mathrm{C}$ & $\mathrm{Q}_{1}^{45-25}=\frac{\theta_{\mathrm{s}(25)}}{\theta_{\mathrm{s}(45)}}$ & $\begin{array}{c}1.135^{20}=\frac{\theta_{s(25)}}{2.088} \\
\theta_{s(25)}=26.281 \text { days }\end{array}$ \\
\hline & at $10^{\circ} \mathrm{C}$ & $\mathrm{Q}_{1}^{45-10}=\frac{\theta_{\mathrm{s}(10)}}{\theta_{\mathrm{s}(45)}}$ & $\begin{array}{c}1.135^{35}=\frac{\theta_{s(10)}}{2.088} \\
\theta_{s(10)}=175.625 \text { days }\end{array}$ \\
\hline & at $4^{\circ} \mathrm{C}$ & $\mathrm{Q}_{1}^{45-4}=\frac{\theta_{\mathrm{s}(4)}}{\theta_{\mathrm{s}(45)}}$ & $\begin{array}{c}1.135^{41}=\frac{\theta_{s(4)}}{2.088} \\
\theta_{s(4)}=357.458 \text { days }\end{array}$ \\
\hline
\end{tabular}


Figure 1

A schematic diagram of characterization of spray-dried Gac aril powder

Fresh Gac aril preparation

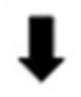

Production of spray dried Gac aril powder

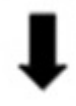

Gac aril powder packaging<smiles>C1CCC1</smiles>

Laboratory analysis

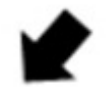

Physicochemical properties

- Moisture content

- Water activity

- $\mathrm{pH}$

- Color

- Water solubility index

- Bulk density

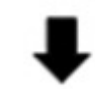

Carotenoid content

- Total carotenoid

- $\beta$-carotene

- Lycopene 
Figure 2

Scanning Electron Microscopic (SEM) images of Gac aril powders dried at different spray drying inlet temperatures; A-C: at $140^{\circ} \mathrm{C}$; D-F: at $160^{\circ} \mathrm{C}$; G-I: at $180^{\circ} \mathrm{C}$ Magnification: A, $D, G \times 1,000 ; B, F, H \times 1,500 ; C, F, I \times 5,000$

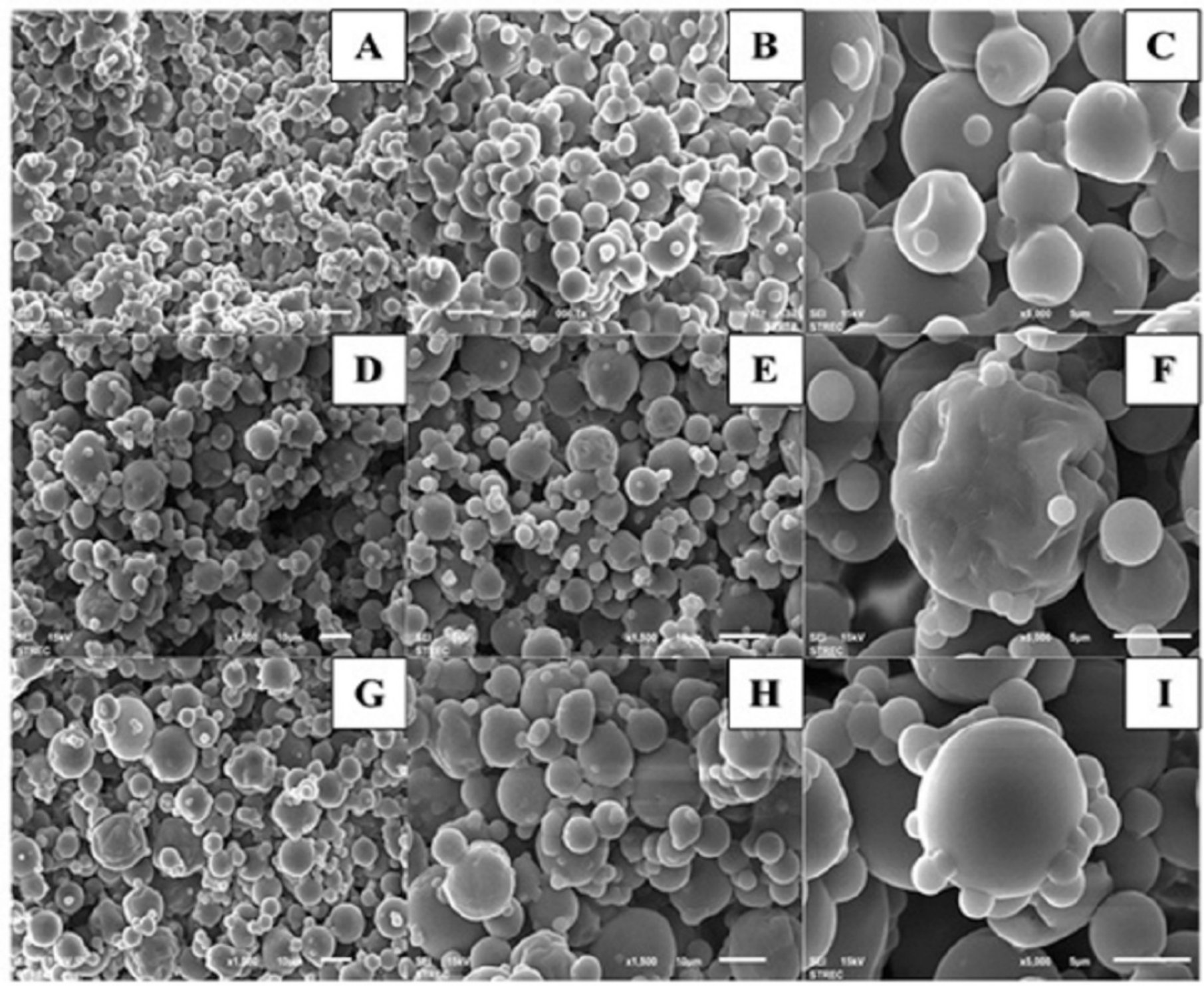


Figure 3

$\beta$-carotene content and its reduction (\%) of spray-dried Gac aril powder stored at $45^{\circ} \mathrm{C}$
(A) and $55^{\circ} \mathrm{C}(\mathrm{B})$

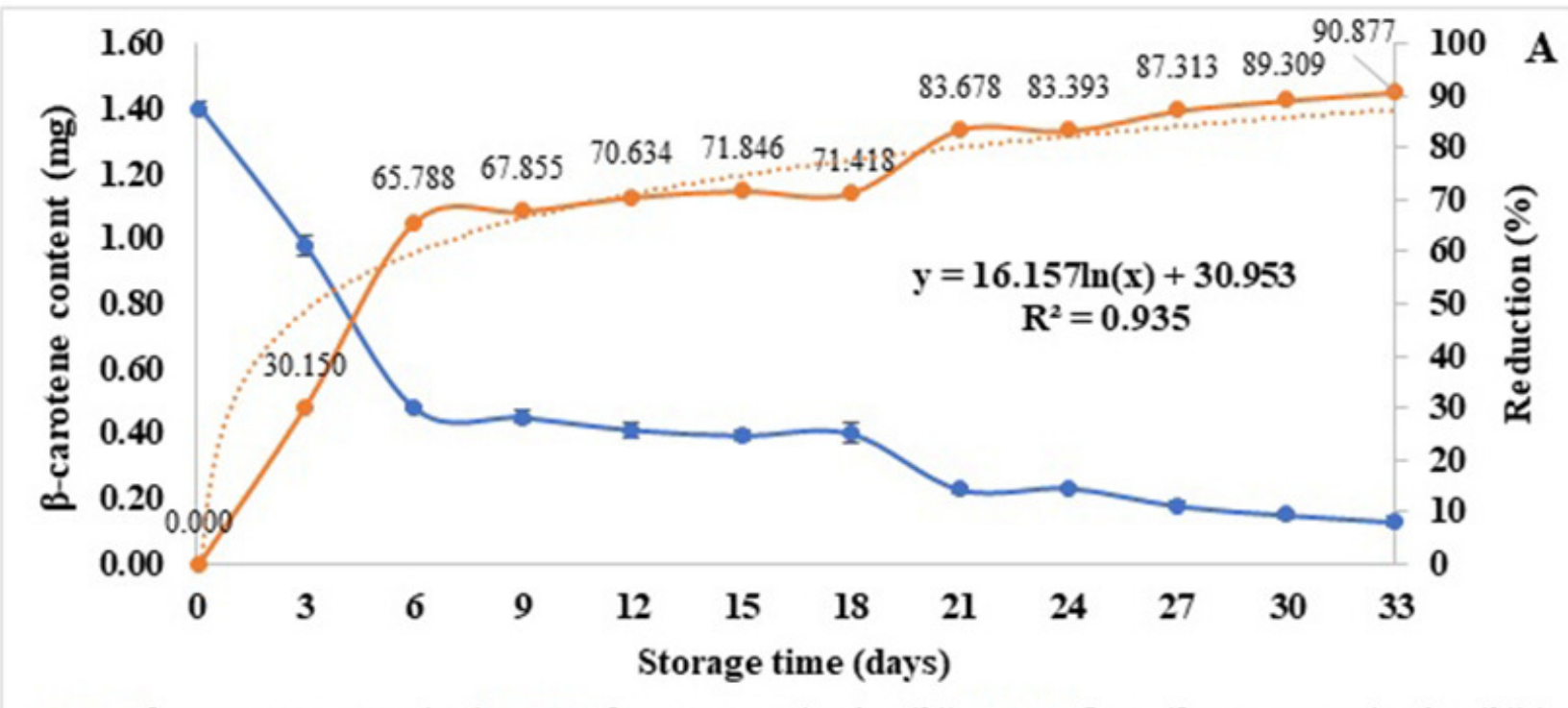

$\longrightarrow \beta$-carotene content $(\mathrm{mg})-\beta$-carotene reduction $(\%)$

Log. ( $\beta$-carotene reduction (\%))

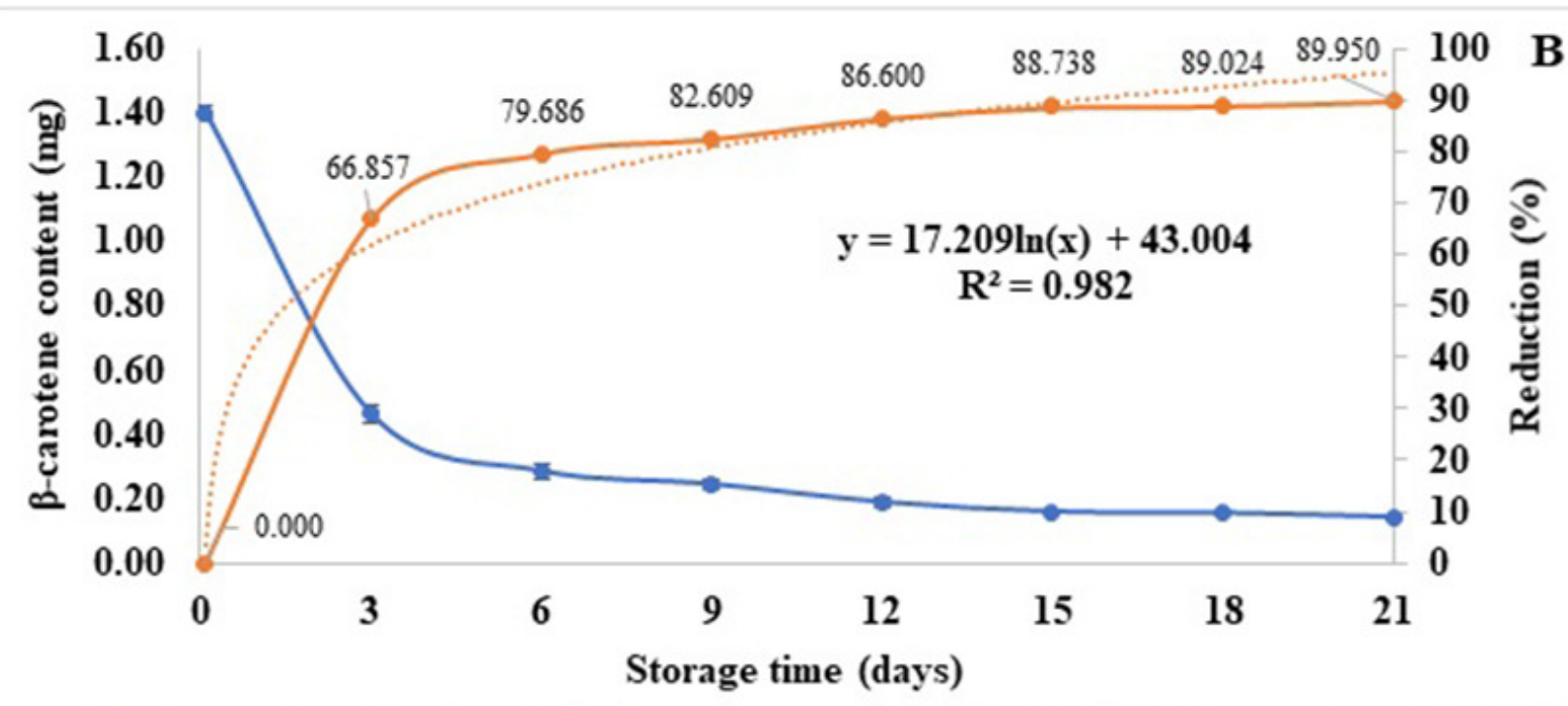

$\longrightarrow \beta$-carotene content $(\mathrm{mg}) \longrightarrow \beta$-carotene reduction $(\%)$

Log. ( $\beta$-carotene reduction (\%)) 
Figure 4

Lycopene content and its reduction (\%) of spray-dried Gac aril powder stored at $45^{\circ} \mathrm{C}(\mathrm{A})$ and $55^{\circ} \mathrm{C}(\mathrm{B})$

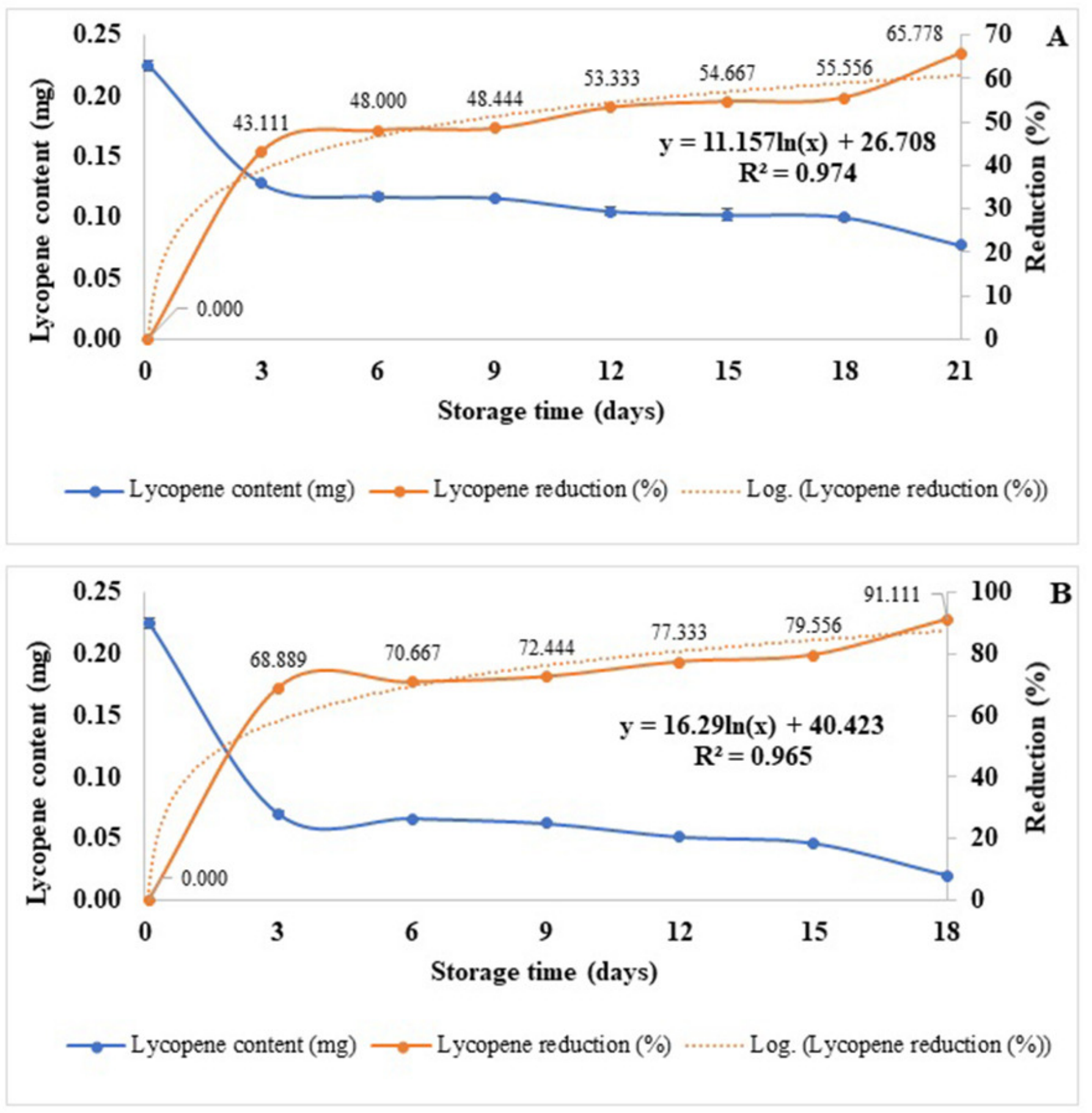

